\title{
Implant-supported crowns insertion in patient receiving chemotherapy
}

\author{
${ }^{1}$ Michael Josef K.K., ${ }^{1}$ Harry Laksono, ${ }^{2}$ Cindy Karina Hartono \\ ${ }^{1}$ Staff of Prosthodontic Dentistry Department \\ ${ }^{2}$ Post Graduate Student of Prosthodontic Dentistry Department \\ Faculty of Dental Medicine Airlangga University \\ Surabaya, Indonesia
}

Corresponding author: Michael Josef K.K., Email: josef_310563@yahoo.com

\section{ABSTRACT}

The clinical results of a case demonstrating dental implant insertion in a patient receiving chemotherapy is the focus of this report. A 74-year-old male patient came on his own accord because five units of porcelain long bridge in his right mandibular region were loosened. The one abutment tooth had a severe problem due to the periodontal problem (tooth 47), and teeth 43 and 44 were treated with root canal treatment, intrapulp post and porcelain crowns. After insertion of the fixture bone level implant, the patient is diagnosed with lymphoma and chemotherapy is performed for treatment. Clinically, the implants had no mobility, with no apparent exudate or bleeding upon probing 1 year after. At the time second procedures were performed, the dental implants had provided support for the abutments. One of the abutments was changed with anatomic abutment due to realignment of prosthesis position. Finally, three crowns porcelain fused to metal were used as final restorations and harmonized occlusion was achieved. The following is a discussion of the purposes and technique used for the insertion of these dental implants.
\end{abstract}

Keywords: dental implants, dental porcelain, dental abutments, crowns, lymphoma

\section{INTRODUCTION}

A dental crown is a restoration that replaces the top part of the tooth. A single tooth that needs to be completely replaced can be restored utilizing an implant-supported crown. The crown is usually porcelain, which gives a natural look to the restoration. It is supported by a titanium "root" and post, implanted into the jawbone. The implantcements thatartificial tooth, ensuring that the crown and teeth are firmly fit and avoiding position shifting. An implant-supported crown looks such as the natural form, size and color with the teeth and provides a wonderful smile. ${ }^{1}$

A dental implant is indeed a titanium post (like some kind of teeth root) that is located under the gum line and puts the artificial tooth in the jawbone in it. A healthy gums and enough bone to support implants is necessary before placing an implant. Many implants have three parts: the implant in bone, the abutment (or connector) which holds the tooth, as well as the crown tooth. The crown is like a tooth and looks like the others around. The abutments are made from various materials, usually titanium, but also gold or zirconia. The crown is applied to the abutmentusing a special type for dental cement. Wellconstructed dental implants connect with the tooth and the abutment very closely. This is necessary for the implant's long-term maintenance. ${ }^{2}$

Implant placement in patients with malignant disease and benign tumors presents special dif- ficulties. Patients with cancer can have oral toxic effects in the form of antineoplastics agents. One of the treatments for patient with cancer is chemotherapy. The goal of treating cancer with chemotherapeutic agents would be to prevent cancer cells from multiplication, invading, metastasizing, and ultimately killing the patient. While some local and systemic causes might be contraindications to treatment by dental implants, the successful rate of dental implants for patients that have received chemotherapy remain unclear. ${ }^{3}$ This case report describes a patient undergoing chemotherapy for lymphoma with successful survival of dental implants inserted in the mandibula.

\section{CASE}

A 74-year-old male patient came on his own accord because five units of porcelain long bridge in his right mandibular region were loosened. The one abutment tooth had a severe problem due to the periodontal problem (tooth 47).

Patient wanted to have implant treatment with fixed restoration because he had experienced with the fixed restoration before in another region, so the prosthodontic treatmentoption was using implant supported crowns.

\section{MANAGEMENT}

The abutment, teeth 43 and 44 were treated with root canal treatment, intrapulp post and porcelain crowns. Three bone level dental 
implant fixtures were inserted in $45,46,47$ regions.

After insertion of the fixture, the patient was diagnosed with lymphoma and chemotherapy was performed for treatment. The implants were checked after 1 year following insertion.
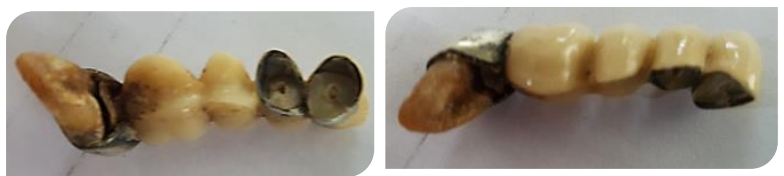

Fig 1 Five units porcelain long bridge were loosened.

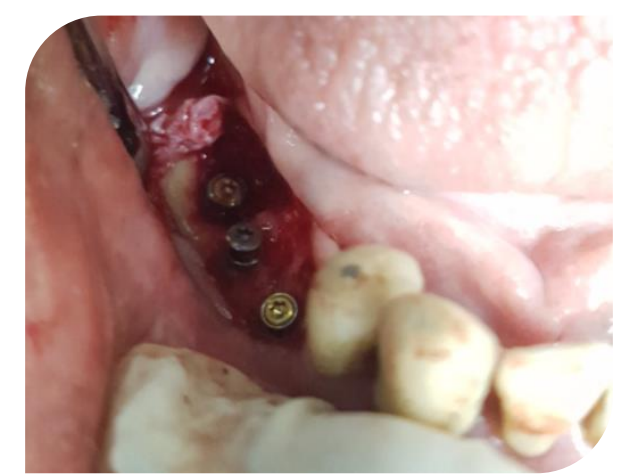

Fig 2 Three bone level dental implant fixtures were inserted.

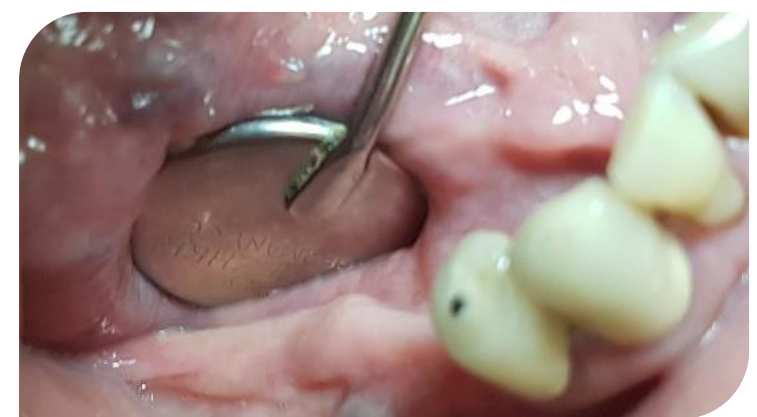

Fig 3 Clinical intra oral examination 1 year after insertion

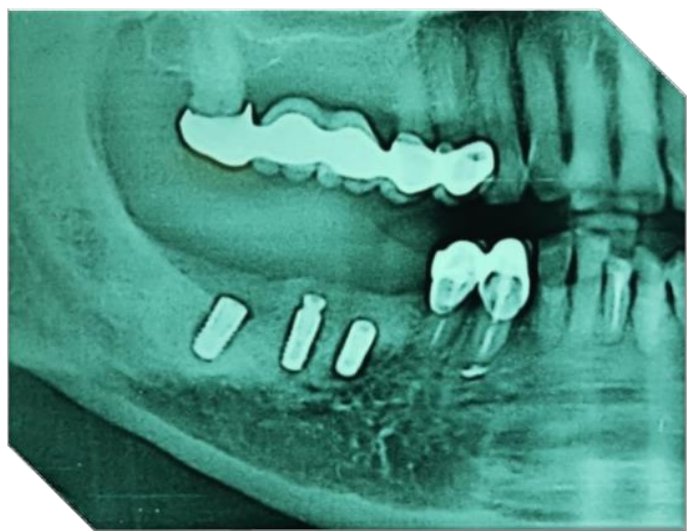

Fig 4 Radiograph examination 1 year after insertion.

Clinically, the implants submerged in soft tissue, with no apparent exudate or bleeding. The panoramic radiograph shows the bone appeared to be integrated to the surface of the implant, and relatively mature and healthy.

At the time second procedures were performed, the dental implants had provided support for the abutments.

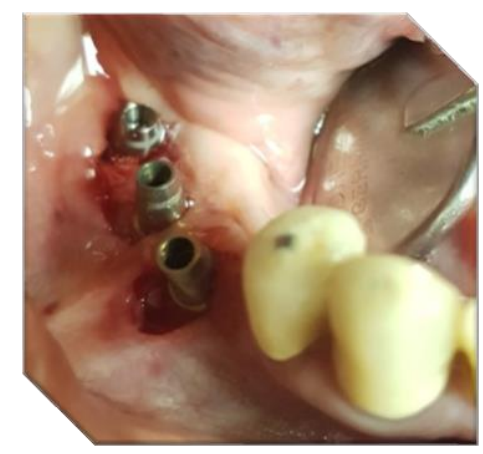

Fig 5 Abutment at second procedures.

Three weeks upon the second operation, the dental implants were in a state of health and functioning in their intended purpose, the mucosa had a full recovery and the impression was done. One of the abutments was changed with anatomic abutment due to realignment of prosthesis position.

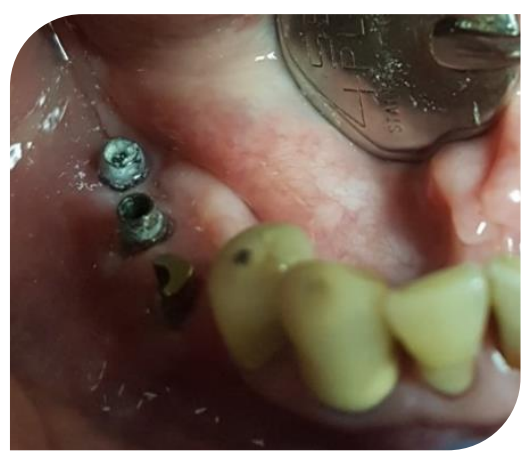

Fig 6 One abutment was changed with anatomic abutment.

Finally, three crowns porcelain fused to metal were used as final restorations and harmonized occlusion was achieved. Panoramic view was taken 6 months after the treatment had fully been accomplished.
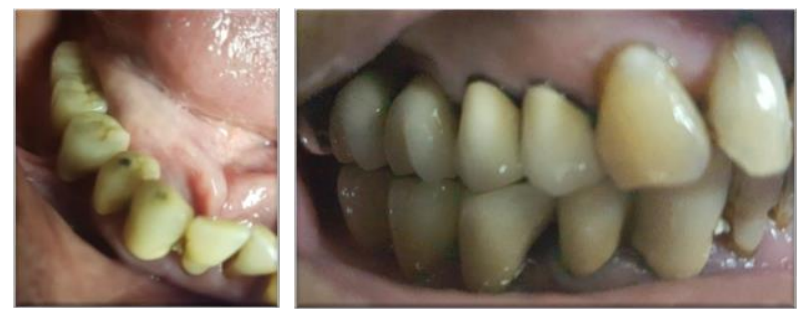

Fig 7 Three crowns porcelain fused to metal. 


\section{DISCUSSION}

Dental implants were widely used and are regarded to be one of many treatment options which can be used to replace missing teeth. The number of implant-supported therapy choices has been effectively used to substitute a single tooth, various teeth and a totally edentulous jaw. This achievementrelies on the capacity of implant material to incorporate into the surrounding tissue.

Cancer patients can suffer oral toxic effects to antineoplastic therapy in the form of chemotherapy. This risk is driven by a variety of variables, including elevated oral mucosal cell turnover rate, oral microflora variety and complexity, or soft tissue trauma during ordinary oral function. Main oral complications of chemotherapy are mucositis, neurotoxicity, susceptible to infections, dental, salivary and taste alterations, and the development of osteonecrosis.

When placing dental implants, it should be known that even a series of metabolic changes occur around the implant, leading to the formation of bone closely linked to the implant surface (osseointegration). Implants can be osseointegrated while the bone and surrounding soft tissues heals and, if chemotherapy is to be given, implants can normally have osseointegrated before the chemotherapy. ${ }^{4}$

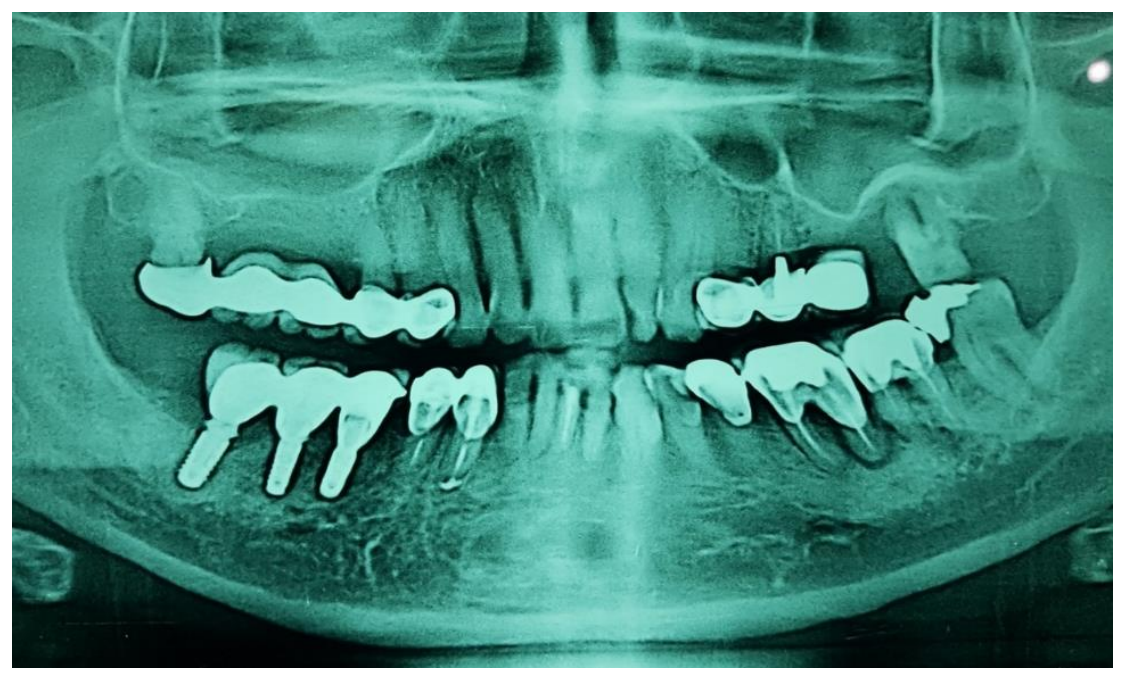

Fig 8 Panoramic radiograph 6 months after treatment.

Table 1 Dental treatment before, during and after chemotherapy ${ }^{5}$

\begin{tabular}{|c|c|c|}
\hline $\begin{array}{l}\text { TREATMISNT BSFORE } \\
\text { CHIMMOTHISRAPY }\end{array}$ & $\begin{array}{l}\text { TREATMISAT DURING } \\
\text { CAIEMOTHISRAPY }\end{array}$ & $\begin{array}{l}\text { TREATMISNT AFTFR } \\
\text { CEIIMOTHIIRAPY }\end{array}$ \\
\hline $\begin{array}{l}\text { - The dentist should consult the } \\
\text { oncologist to determine the current } \\
\text { condition of the patient and the type } \\
\text { of treatment planned. }\end{array}$ & $\begin{array}{l}\text { The oncologist should be consulted in } \\
\text { order to know the degree of immune } \\
\text { suppression of the patient. }\end{array}$ & $\begin{array}{l}\text { - The dentist should consult the } \\
\text { oncologist to determine immune } \\
\text { competence. }\end{array}$ \\
\hline $\begin{array}{l}\text { - Exhaustive examination of the oral } \\
\text { cavity. discard periapical lesions } \\
\text { and or bone alterations, and the } \\
\text { evaluation of periodontal health. } \\
\text { - Denture fitting should be checked, } \\
\text { with readjusment or removal } \\
\text { of those prostheses that prove } \\
\text { traumatic. } \\
\text { - Radiological study: intraoral } \\
\text { (periapical and bitewing) and } \\
\text { panoramic. }\end{array}$ & $\begin{array}{l}\text { - } \begin{array}{l}\text { Treatment of the complications } \\
\text { of chemotherapy } \\
\text { xerostomia...). }\end{array}\end{array}$ & $\begin{array}{l}\text { - Insist on the need for routine } \\
\text { systematic oral bygiene. } \\
\text { - Use of chlorhexidine rinses and } \\
\text { fluorization. }\end{array}$ \\
\hline $\begin{array}{l}\text { - Generalprophylacticmeasures:tartar } \\
\text { removal, dental fluorization and } \\
\text { rinses with } 0.12 \% \text { chlorhexidine. }\end{array}$ & $\begin{array}{l}\text { - Continued patient reminder of the } \\
\text { need to maintain strict dental hygeiene } \\
\text { is indicated, with the added use of } \\
\text { chloriexidine rinses and fluorization. }\end{array}$ & \\
\hline $\begin{array}{l}\text { - The patient should be informed of } \\
\text { the complications of treatment. }\end{array}$ & $\begin{array}{l}\text { - Analgesics: paracetamol/metamizol. } \\
\text { - NO NSAID. } \\
\text { - Antibiotics: dose adjustment is } \\
\text { required according to the observed } \\
\text { creatinine clearance values in patients } \\
\text { with kidney problems. }\end{array}$ & \\
\hline $\begin{array}{l}\text { - Teeth that are non-viable or present a } \\
\text { poor proguosis should be removed. } \\
\text { - Minor surgery: al least two weeks } \\
\text { before chemotherapy- } \\
\text { - Major surgery: } 4-6 \text { weeks before } \\
\text { chemotherapy. }\end{array}$ & $\begin{array}{l}\text { No elective dental treatment should be } \\
\text { carried out. } \\
\text { ONLY emergency dental care. }\end{array}$ & - Elective dental treatment. \\
\hline
\end{tabular}




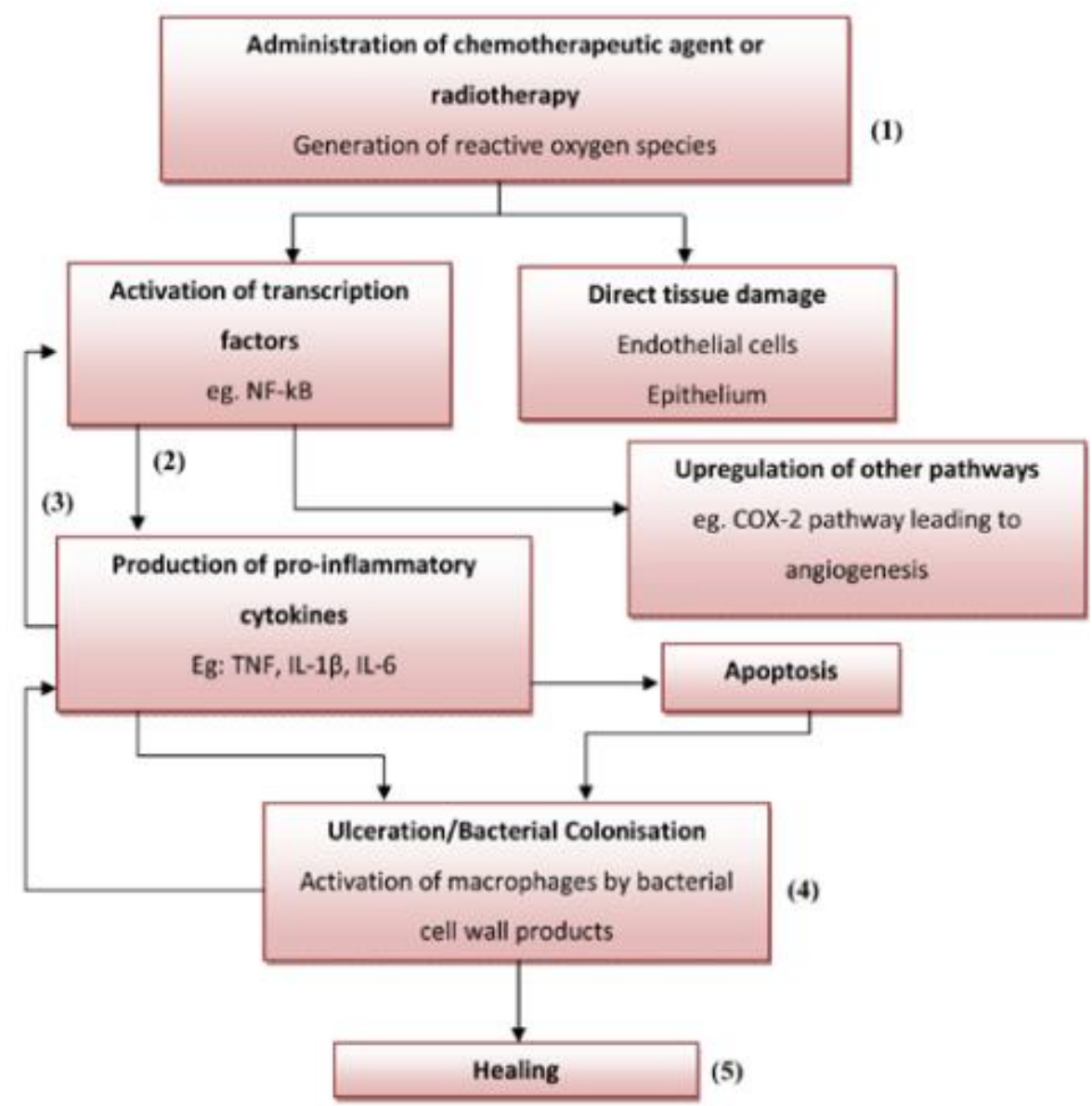

Fig 9 Administration of chemotheraputic agent or radiotherapy. ${ }^{5}$

This table is the guideline for dentist to treat the patient before, during, and after chemotherapy procedure and administration of chemotheraputic agent or radiotherapy. ${ }^{5}$

Implant therapy is not absolutely forbidden to be done in chemotherapy patient. Implant can be done by considering a least four factors, such as patient's health, oral hygiene, chemotherapy standard operating procedure, and approval from the oncologist. A good follow up and communication should be done among patient, dentist, and oncologist.

\section{REFERENCES}

1. Rao BHS, Bhat V. Dental implants: a boon to dentistry. Med Health Sci 2015; 3(1): 131-7.

2. Duraccio D, Mussano F, Faga MG. Biomaterials for dental implants: current and future trends. J Mater Sci 2015; 50(14).

3. Aeran H, Nautiyal V, Kumar V, Uniyal S. Implant Supported Overdenture in The Patients with History of Radio and Chemotherapy for The Prostate Malignancy. National J Maxillofac Surg 2015; 6: 200-5.

4. Dantas MVM, Verzola MHA, Sanita PV, Dovigo LN, Cerri PS, Gabrielli MAC. The influence of cisplatinbased chemotherapy on the osseointegration of dental implants: an in vivo mechanical and histometrical study. Clin Oral Implants Res 2019; 30(7): 603-16.

5. Lopez CB, Esteve GC, Perez SMG. Dental treatment considerations in the chemotherapy patient. J Clin Exp Dent 2011; 3(1):31-42. 